\title{
A Diagnosis of the Post-Apartheid Public Procurement Regime in South Africa
}

\author{
Bongani Mwale
}

\begin{abstract}
The purpose of this study is to analyse the progress that the post-Apartheid public procurement regime has made in South Africa in achieving its mandate of addressing socio-economic imbalances created by Apartheid. Based on the desktop literature review and research design, this study explores, through a conceptual analytical approach, the pros and cons that have characterized the South African public procurement regime to date. The study appreciate and acknowledge tremendous progress made to date in ensuring that the South African public procurement regime meets the international standards governing supply chain management processes. Nevertheless, research findings have shown some shortcomings in that the current procurement regime as it recycle enterprises without really creating sustenance. This has resulted in most SMEs benefitting from the government procurement, struggling to survive outside public procurement. The current B-BBEE framework have shown fundamental gaps, and consequently created of more black business managers than black industrialists who are sustainable entrepreneurs. Big companies with the capacity to respond to the seven elements of the scorecards hire black executives and pay them salaries while they share dividends and profits. Thus, the Public Procurement in South Africa needs to be constantly evaluated, monitored and adjusted accordingly, considering the highly dynamic contemporary business environment. This is in the ambit of: lack of proper knowledge, skills and capacity; non-compliance with SCM policy and regulations; inadequate planning and the linking of demand to the budget; Accountability, fraud and corruption; inadequate monitoring and evaluation of SCM; unethical behaviour; decentralization of the procurement system without proper regulated mechanism and Irresponsiveness of the BBBEE policy. The study concludes by recommending a revamp of the B-BBEE framework in its current form in order to make it more responsive and effective.
\end{abstract}

Keywords: Public Procurement, Preferential Procurement Policy Framework, Broad-Based Black Economic Empowerment, Supply Chain Management

DOI: $10.7176 / \mathrm{EJBM} / 12-29-02$

Publication date:October $31^{\text {st }} 2020$

\section{Introduction}

\subsection{Definition of Public Procurement}

Public procurement entails the purchasing or acquisition of work, goods or services by the public entities such as government departments or local authorities (European Union, 2017). Bakar, Peszynski, Azizan, Pandiyan and Sundram (2016) assert that the procurement profession involves sourcing the correct goods and services that entities and individual end-users require from the right suppliers in the market at the right price. Nijaki and Worrel (2012) affirm that procurement is a practice that involves acquiring goods and services from a supplier on behalf of an end-user. Bakar (2016) echoed the same sentiment in that the procurement process is a business venture whose goal is to bridge the gap between the individual user and the supplier by means of providing required goods and services. Loosemore (2016) and Tuomela-Pyykkönen, Aaltonen and Haapasalo (2015), in their respective studies, concede that procurement involves the provision of goods and services to the end user in a way that will enhance socio-economic and environmental development and sustenance respectively.

Suarishvili (2016) adds that much of the public procurement is carried out through a tendering process which involves a binding offer to complete particular work, deliver goods and services in respect to the buyer's specified terms and conditions. The tendering process involves activities such as market research, coming up with a procurement strategy and specifications for the goods and services that the buyer requires, putting in place all the required tendering documents which are composed of technical specifications, criteria for supplier selection, terms and conditions of the contract as well as the follow-up procedures (Suarishvili, 2016).

\subsection{The Importance of Public Procurement}

\subsubsection{The Global Perspective}

McKinsey (2017) asserts that in-spite the challenges involved in measuring it, public procurement plays a pivotal role of going beyond growing and sustaining the economy of any given state. Public sector productivity has a crucial impact in determining the performance of the national economy as well as the overall well-being of the society. Governments or state departments are the principal, and in some cases the sole service providers of key essential services to citizens like education, health, social services, transportation and infrastructure development (Lundberg \& Marklund, 2018). In other words, governments command the biggest shares in most sectors that provide key services to the public. Research has shown that governments in OECD countries are responsible for 
$70 \%$ of final consumption expenditure on health goods and services and for $84 \%$ of final consumption expenditure on education (OECD, 2017). Government expenditure is allocated more toward the education, health, social services and environmental sectors.

This has been the case especially in Finland, where government expenditure constitutes the biggest share of GDP than in the majority of OECD countries. In the period ranging from 2009 to 2015 , government expenditure rose by 9.3 percent, leading to an increase from $46.8 \%$ to $56.1 \%$ of the GDP, thus making Finland the secondhighest public spending country in the OECD. Of that government expenditure, $30.8 \%$ (higher than the OECD average of $29.1 \%$ ) was spent through public procurement. Thereafter, the Finnish government embarked on a massive spending review in the year 2015 in an effort to consolidate strategies meant to reduce public expenditure while boosting revenue (OECD, 2016).

McKinsey (2017) recently discovered that the global fiscal gap of USD 3.3 trillion could possibly be addressed by 2021 through better management of public spending while at the same time emulating practices of best performing countries. The same research also discovered that through proper spending of current funds in the health care sector, the average healthy life expectancy would be increased by 1.4 years. If proper procurement measures were to be followed by governments, a $1 \%$ saving in public procurement expenditure could account for approximately 43 billion EUR per year in OECD countries (OECD, 2017).

1.2.2. The South African and Developing Countries' Context

In South Africa, public procurement has been deemed a major government policy lever designed to accomplish economic objectives to previously disadvantaged minorities in the country. The National Development Plan (NDP) has orchestrated the public procurement process both at public and private sector levels in order to accomplish industrial development while at the same time generating employment opportunities and growing the economy (National Planning Commission, 2011). The Industrial Policy Action Plan (IPAP) Report carried out by the Department of Trade and Industry in 2015 asserts that public procurement constitutes above 15\% of the GDP for most developing economies. Thus the survey clearly demonstrates the magnitude to which both the private and the public sector procurement contribute towards the local economy and economic development (Department of Trade and Industry, 2015). The report issued by the UNDP African Facility for Inclusive Markets (AFIM) (2013) states that public procurement accounts for a very vast portion of national budgets, representing approximately $25 \%$ to $30 \%$ of GDP in developing nations. The same survey indicates that South Africa has the most robust inclusive public procurement program in the sub-Saharan region and this is achieved through its Broad-Based Black Economic Empowerment (B-BBEE). Lee and Sehoole (2015) assert that regionally and internationally, South Africa is pitched as a major contributor in terms of human capital capacity building and that it is popularly regarded as an emerging provider of higher education by virtue of its ability to attract interest of foreign students and scholars from across the globe.

Mzobe (2015) argues that education especially in African countries, significantly determines the social context and perspectives with regards to inclusive development. Bolton (2008) states that the legislative environment in South Africa is favourable to the attainment of social, economic and environmental objectives of sustainability that comes through the procurement system. It therefore argues that, virtue of their large buying power, the state and organizations have the potential to make a crucial and significant contribution in achieving sustainable procurement while at the same time influencing markets in a responsible and sustainable manner (Hank et al., 2008). Mashele (2016) asserts that the acquisition of goods and services from local suppliers is a conduit that facilitates the creation of sustainable jobs and driving sustainable procurement and economic growth with an inherent direct positive impact of the country's fiscal policy.

\section{Research Method}

This article is based on exploratory research method which entails an conceptual analytical approach which regards concepts as classes of objects, events, properties or relationships (Funer, 2004). The technique thus involves the definition of concepts through the identification and specification of the conditions under which any entity or phenomenon is (or could be) classified under the concept in question. In order to get a better understanding of procurement practices in the South African public sector a conceptual analysis is employed. To complete this article, relevant public procurement literature sources, pertinent documents procurement policy from the National Treasury (NT) website, newspaper reports alongside other research documents relating to procurement in the South African public sector were reviewed and analysed. In light of the discussed method, the survey examined: (1) the importance of public procurement in general (2) public procurement practices in South Africa, (3) the challenges of public procurement in South Africa, and (4) the way forward for public procurement in South Africa.

\section{Literature Review}

\subsection{Public Procurement in the South African Public Sector}

2.1.1. Background

Public procurement reforms in South Africa started in 1995 where the main thrust was inclined firstly toward the 
promotion of principles of good governance and secondly the ushering in of a preference system whose mandate was to address certain socio-economic objectives (National Treasury, 2016). These reforms were contained in the Public Finance Management Act (PFMA), Municipal Financial Management Act (MFMA) (Act No 56 of 2003 ) and the PPPFA (Act No 5 of 2000) (NT, 2005).

The procurement systems and provisioning remained given the fact that tender boards were responsible for procurement whilst provisioning was underwritten by norms and standards within the logistics system driven by the National Treasury. Thus, as a result, proper financial management systems within the government remained a bone of contention. In the same way the logistics system as a tool for asset management raised concerns in the wake of improper handling and management of movable assets within the government environment. Concurrently more focus was placed on the development of integrated infrastructure and the unlocking of state property to contribute towards the optimization of resources (NT, 2016).

Through the effective and efficient application of competitive procurement processes, the World Bank (2016) estimated that South Africa had the capacity and an opportunity to generate savings for professional services by $\$ 1.14$ billion that would contribute towards the growth of its GDP by 0.5 point. As the custodian of the management and administration of public finances in South Africa, the National Treasury conceives the fact that the procurement or acquisition of public goods, services and construction works is an enabling mechanism, which plays a crucial and central role in delivering services to the public by the government. As a result, it promotes and facilitates a strategic positioning of an enabling effective and efficient procurement environment, taking into consideration the large scale and the power of the public purse.

Cant \& Wiid (2013) assert that at a local procurement scale, small and medium-sized enterprises (SMEs) constitute $60 \%$ of formal employment in South Africa. It is thus against this background that SMEs are regarded as significant positive players towards job creation and economic development. SMEs exist in different economic sectors and may pursue a variety of business operations (Mutalemwa, 2015). Marais (2012) attests that the support of business for SMEs, which is connected to procurement and supply market access through initiatives for community development, carries the capacity and potential to enhance market competitiveness and produce broad economic development opportunities locally.

2.1.2. Preferential Procurement Policy Framework Act (2000) \& the Broad-Based Black Economic Empowerment Act (2003).

In its efforts to empower the Historically Disadvantaged Individuals (HDIs), the government through the Preferential Procurement Policy Framework Act (PPPFA, 2000) put concerted efforts to address the disparity by way of granting preferential treatment in procurement activities. Through this Act, all government entities are obliged to administer the tendering process based partly on the supplier's "scorecard" on broad-based black economic empowerment (B-BBEE) criteria. This was meant to bridge the gap that was created through the exclusion of non-white citizens who included the blacks, coloureds, Indians and second-generation Chinese citizens.

In order to correct the still narrow terms and conditions to promote black empowerment prior to 2003, Government endorsed the alteration and came up with the Broad-Based Black Economic Empowerment Act in 2003 (B-BBEE Act) whose principal agenda was to put in place mechanisms meant to accelerate the entry and participation of black people into the mainstream economy. The B-BBEE Act established a code of conduct that would ensure that all public entities including the State Owned Enterprises (SOEs) are obliged to adhere to the Codes in the Act when making decisions which include amongst others, procurement. This indicates how the South African government is committed to growing the economy while at the same time implementing measures designed to promote the development of both SMMEs and HDIs.

Arancha González (2017) asserts that developing countries in Africa, Asia and South America have comprehended the importance of inclusive public procurement policies and practices through promoting preferential procurement systems. In Kenya for example, the government has mandated set-asides for women suppliers in specific sectors of the economy and this has helped empower women who were historically excluded from the mainstream economy. Research has shown that these women owned enterprises have had a tremendous contribution towards the national GDP while at the same time employing more women thereby bridging the gender disparity gap as far as equal employment opportunities are concerned (Arancha González, 2017). Chile is also one country that has successfully developed a robust preferential procurement system whose goal is to bring on board and empower women through active participation in economic activities. This was achieved by means of establishing supportive systems of training and certifying women entrepreneurs, establishing and promoting women's associations, and revisiting and revamping regulatory reforms. Chile's public procurement system has made it very easy for SMEs to access and participate in the mainstream economy. Statistics showed that the share of women participation in public procurement was pegged at $37 \%$ in 2016 , this being equivalent to more than 21,345 women who managed to quote, offer, or take purchase orders. 


\subsection{Public Procurement Challenges in South Africa}

Ambe (2012) asserts that as much as public procurement has made phenomenal and significant strides in South Africa, the profession still faces enormous hitches and predicaments that have often derailed its quest to achieve economic growth through an inclusive approach that addresses past socio-economic imbalances. It is also vital at this juncture to point out that the Supply Chain Management (SCM) is an integral part of procurement in the South African public sector. Thus, the former plays a crucial role in the management and administration of public procurement practices. Nevertheless, in-spite of the application of the SCM, public procurement as indicated earlier on is confronted by numerous challenges, which include:

\section{- Lack of proper knowledge, skills and capacity}

Sheorai (2007) notes that one of the greatest obstacle to the successful implementation of the public procurement process in South Africa is the shortage of skills and capacity. This is in-spite of the efforts by the National Treasury in providing support in providing training materials to government departments, municipalities and municipal entities (National Treasury, 2005). Migiro and Ambe (2008) pointed out that although many SCM practitioners have been exposed to workshops and seminars, they still fall short of the competencies necessary for the effective implementation of the procurement process. As a result the whole process has resulted in poor governance McCarthy (2006).

\section{- Non-compliance with policies and regulations}

The SCM operates within a framework of various policies and regulations (National Treasury, 2005). Research has shown that adherence to these guidelines has been a challenge. Matthee (2006) points out that the failure to comply with the rules and regulations revolve around the reluctance or negligence surrounding the application of a competitive process for both quotations and bids, and the improper utilization of the preference points system. Van Zyl (2006) also noted that inappropriate bid committees; incompetent suppliers, passing over of bids for incorrect reasons; use of inappropriate procurement process with regards to the thresholds; validity periods extensions and the incorrect utilization of the limited bidding process constitute factors that have negatively impacted on the effective implementation. Flawed control measures in the adjudication of bids; the appointment of bid committee members not aligned to policy requirements; and unjustified reasons for deviations from SCM procedures all work against any efforts to see the South African public procurement achieve its goals and objectives (Ambe \& Badenhorst-Weiss 2016).

\section{- Inadequate planning and linking demand to the budget}

Demand management is a very crucial component that is the integral part of the SCM process. It is a process which ensures that a department's procurement process is done at the right time, at the right place and at the right cost. Nevertheless, a number of state entities are still battling to adequately plan and marry demand to budget (Ambe \& Badenhorst-Weiss, 2016). Coming up with accurate and realistic strategic plans can never be overestimated. Luyt 2008 noted that some public entities find it difficult to establish and quantify the needs of their potential customers or come up with realistic cost estimation techniques nor accurately track, control or report on expenditure. Thus SCM practitioners need to better their planning and budgeting skills for effective implementation of the SCM.

\section{- Accountability, fraud and corruption}

Soudry (2007) states that accountability plays a pivotal role in public procurement. Failure to put in place structures that will promote accountability will inevitably result in increased corruption and misuse of funds (Jeppesen, 2010). Mahlaba (2004) laments that fraud and corruption have resulted in the loss of millions of rand each year. Mahlaba state that it is for this reason that Government have put measures in place to curb such unprecedented scams through various instruments, like the then Directorate of Special Operations (the Scorpions), the Asset Forfeiture Unit, the Public Protector, the Special Investigation Unit, Commercial Crime Units, Internal Audit Units, Investigation Units within departments, and the appointment of forensic consultants. Discontentment among South Africans, whose hopes for socio-economic liberation and improvement have begun to wane off, has been on the rise in the face of poor governance, poor service delivery and disillusionment with empowerment policies (De Lange, 2011). The Public Service Commission Committee (2011) recorded that about 7766 cases of corruption had been reported through the National Anti-Corruption Hotline in the period spanning September 2004 to June 2010. De Lange (2011) states that in 2012 alone about 20 per cent of the state's procurement budget alone vanished because of fraud and corruption. Pauw (2011) asserts that there is an urgent need for the government to revisit and review the current control systems in order to mitigate the mismanagement and administration of funds.

\section{- Inadequate measures for monitoring and evaluation of SCM}

Acevedo, Rivera, Lima \& Hwang (2010) argue that robust monitoring and evaluation structures and systems need to be put in place in a bid to provide the basis for sound governance and accountability. This will help detect any deviation or non-compliance to the prescribed rules and regulations. Business Day report (2011) noted that many are times when procurement practitioners have spent millions of rand by transgressing laws and regulations.

\section{- Decentralization of the procurement system without proper regulated mechanism}

Government procurement in South Africa has been decentralized to departments, provinces and municipalities and the rationale behind this approach ranges from local knowledge to building of relationships with stakeholders in 
the respective catchment area or market (Handfeld, Monczka, Guinipero \& Patterson, 2011). Decentralization also result in better responsiveness to purchasing needs and is closer to suppliers and taking ownership of decisions that impact on one's own budget (Handfeld 2011). However, centralization also comes with its own package of advantages such as cost reduction, elimination of duplication of purchasing, better qualified and skilled procurement personnel. The only challenge that comes with centralized procurement is the need for efficient contract management and supplier relationship management, and in most cases, this does not exist.

\section{- Ineffectiveness of broad-based black economic empowerment}

In-spite of its efforts to empower all previously disadvantaged groups, the South African Government adopted the Broad-Based Black Economic Empowerment Act (B-BBEEA) whose goal is to increase opportunities for workers and SMEs as well as more representative ownership and management. However, the current BEE provisions have, in many cases failed to promote a broad-based approach. Thus the existing model remains more focused on business transactions that involve already existing assets thereby benefiting a very small number of individuals (Ambe \& Badenhorst-Weiss, 2016). The following shortcomings have emerged in the implementation of BEE:

First, there has been a notable disproportionate emphasis in the area of ownership and senior management issues. This has resulted in 'fronting', speculation and tender abuse. Secondly, the rules and regulations have failed to significantly incentivize the creation of employment, the anticipated support for SMEs as well as the promotion of procurement. Thus, the preferential procurement regulations have worsened the situation through prioritization and privileging ownership well above local production. Finally, research has shown that the B-BBEE regulations tend to penalize public companies as service providers. According to Zuma (2009), the democratic state owns public companies on behalf of the populace while on the other hand B-BBEE regulations do not classify them as 'black empowered'.

The above discussion gives a clear signal that procurement practices in the South African public sector are still constrained by various factors, which can be attributed to insufficient knowledge, skills and capacity. Thus, the South African government needs to go back to the drawing board and find ways to mitigate these challenges. Of paramount importance is a revamp of the B-BBEE framework whose current regulations have not helped much in the achievement of the intended goals and objectives of addressing socio-economic injustices caused by the apartheid era (Ambe \& Badenhorst-Weiss, 2016).

\section{The Way Forward for Public Procurement in South Africa}

In-spite of the challenges that the South African public sector is currently battling regarding procurement, policy makers still have a number of options they can explore to serve the situation such as skills and knowledge development through robust and specialized training interventions, stakeholder involvement in the bidding process as well as streamlined centralization and decentralization for particular goods and services (Ambe \& BadenhorstWeiss, 2016).

\subsection{Skills and Knowledge Development}

Training and development for practitioners and learners remains a critical role of institutions of higher learning and other service providers. Such institutions need to come up with tailor made curricula that will equip practitioners and make them competent enough to meet the needs of the country as far as the rules and regulations of the South African public sector procurement is concerned.

It is crucial that practitioners are equipped with both general procurement skills and industry-specific skills. Under the private sector, practitioners need to have an understanding of the general business environment (enterprise management), while under the public sector learners or practitioners need to have a good command of the legislative environment (drilling learners in to the integrated approach in the administration of procurement taking cognizance of the highly regulated public sector environment). Both sectors call for general procurement skills which include, but are not limited to, a good comprehension of the purchasing and supply environment, sourcing strategies, purchasing and supply tasks, integrated supply management, globalization, and technological evolution (Ambe \& Badenhorst-Weiss, 2016).

\subsection{Stakeholders' Involvement}

Bringing on board key stakeholders such as civic society organizations in the procurement process is crucial if public procurement malpractices are to be mitigated or eliminated. The current status quo of the procurement system is composed of three id committees namely the bid specification committee, the evaluation committee and the adjudication committee. For the sake of good governance that is devoid of unethical and corrupt practices, the inclusion of key stakeholders in the adjudication process is vital. This will also enhance transparency, legitimacy and accountability. Most importantly such an engagement will eventually improve the efficiency of state institutions, bolster proper management of natural resources and ensure better service delivery (Ambe \& Badenhorst-Weiss, 2016). 


\subsection{Strategic Sourcing (Centralisation versus Decentralisation)}

Ambe \& Badenhorst-Weiss (2016) state that the use of centralized and decentralized procurement strategies for different categories of goods and services is one way through which public procurement can be improved. As much as a centralized approach bears the merit for better control and expertise, the decentralized approach is very crucial in some circumstances. Bottleneck items (high risk-low cost items) and strategic items (high risk -high cost items) need to be purchased on centralized basis. On the other hand leverage items (low risk but high cost) can possibly be procured through one agency from where other institutions then order normally through eprocurement, and subsequently distribution takes place on a decentralized basis (Simchi-Levy, Kaminksi \& Simchi-Levy, 2009: 287).

\section{Conclusion \& Recommendations}

Evidence suggest that the procurement regime enacted by the SA democratic government is marked by unclear red tape, which make the cost of entrance to business high and unaffordable to persons starting new businesses. The policy makers should look at the bureaucratic processes and simplify the processes to start and maintain a business by considering establishing a one-stop process, which may see new businesses coming out with all compliance requirements.

Public procurement in South Africa should be viewed as the answer to sustainable socio-economic development to addressing past imbalances perpetrated by the apartheid that excluded Africans and black people from the economic mainstream. The B-BBEE policy initiative adopted by South African government have, to a certain extent, achieved the overall objective of creating a level ground where the historically disadvantaged individuals were given an opportunity to participate in economic activities (Mahmood, 2010). Over and above the proposed way-out, all these efforts may not have yield the desired outcomes unless there is a revamp of the BBBEE to increase the chances of the black majority to participate as owners of sustainable businesses as opposed to being managers large corporates who use their profile to score points on the B-BBEE scorecard.

There is an urgent need to amend some aspects of preferential procurement to facilitate more flexibility in different sectors, while at the same time maintaining strong ties to the main B-BBEE. Thus, the study winds up by giving a set of recommendations intended to guide the improvements of the B-BBEE going forward:

- Development of a B-BBEE monitoring and evaluation framework to monitor actual performance of the B-BBEE policy.

- Amendment of the CSD to facilitate linkage between number of suppliers and supply chain transactional and payment systems, thus enabling an overarching analysis on public expenditure across all state-owned entities.

- The DTI and the BEE Commission to adopt a proactive role in providing policy coherence for a mutual understanding by different state organs regarding the implementation of the B-BBEE.

- Amending the current regulations in order to offset some of the challenges prohibiting the participation of SMEs in public procurement.

- DTI to increase oversight of the sector codes thereby ensuring alignment to the generic codes.

\section{References}

Ambe, I. M. (2016). Public Procurement Trends and Developments in South Africa. Research Journal of Business and Management, 3(4), 277 - 290.

Ambe, I. \& Badenhorst-Weiss, J. (2012). Procurement Challenges in the South African Public Sector. Journal of Transport and Supply Chain Management, 6(1), 242-261.

Arrowsmith, S. (2010). Public Procurement: Basic Concepts and the Coverage of Procurement Rules, in Public Procurement Relations: An Introduction. EU Asia InterUniversity Network.

Bakar, N. A., Peszynski, K., Azizan, N., Pandiyan, V. \& Sundram, K. (2016). Abridgment of Traditional Procurement and E-Procurement: Definitions, Tools and Benefits. Journal of Emerging Economies and Islamic Research, 4(1), 1-17.

Department of Trade and Industry. (2015). Industrial Policy Action Plan 2015. IPAP 2015/16 -2017/18. Pretoria: Department of Trade and Industry.

De Lange S. (2011). Irregular State Expenditure Jumps 62\%. Business Day. Available from: http://www.smartprocurement.co.za/irregular_state_expenditure jumps_62.php\#sthash.YARHk0fX.dpbs.

González, A. (2017). Public Procurement, a Tool to Boost Women's Economic Empowerment. International Trade Centre. Available from: https://www.intracen.org/news/Public-Procurement-a-Tool-to-Boost-WomensEconomic-Empowerment/.

Huang, Y. C., Yang, M. L. \& Wong, Y. J. (2016). Institutional pressures, resources commitment and returns management. Supply Chain Management: An International Journal, 21(3).

Jeppesen R. (2010). Accountability in public procurement - transparency and the role of civil society. United Nations Procurement Capacity Development Centre. Available from: www.unpcdc.org. 
Loosemore, M. (2016). Social Procurement in UK Construction Projects. International Journal of Project Management, 34(2), 133-144.

Mahlaba, P.J. 2004. Fraud and Corruption in the Public Sector: An Audit Perspective. S D R, 3(2): 84-87.

Mahmood, S.A.I. (2010). Public Procurement and Corruption in Bangladesh: Confronting the Challenges and Opportunities. Journal of Public Administration and Policy Research, 2(6):103-11.

Mashele, F. (2016). The Relationship between Sustainability and Compliance in a Procurement Context. MBA Dissertation. Gordon Institute of Business Science, University of Pretoria.

Matthee, C.A. (2006). The Potential of Internal Audit to Enhance Supply Chain Management Outcomes. Master's Dissertation. University of Stellenbosch, Stellenbosch.

Migiro, S.O. \& Ambe, I.M. (2008). Evaluation of the Implementation of Public Sector Supply Chain Management and Challenges: A Case Study of the Central District Municipality, North West Province, South Africa. African Journal of Business Management, 2(12): 230-42.

Mkhize, Z. (2004). Supply Chain Management Conference: Transforming Government Procurement System. Paper presented at the Supply Chain Management Conference. Durban, Republic of South Africa.

Mutalemwa, D. K. (2015). Does Globalisation Impact SME Development in Africa? African Journal of Economic and Management Studies, 6(2), 164 - 182.

Mzobe, N. (2015). The Role of Education and Financial Inclusion in Africa: The Case of Selected African Countries. Master's Thesis. University of Stellenbosch, Stellenbosch.

National Treasury. (2016). 2016 Budget Speech. National Treasury, Republic of South Africa. Available from: www.treasury.gov.za/documents/national\%20budget/2016/speech/speech.pdf.

Nijaki, L. K., \& Worrel, G. (2012). Procurement for Sustainable Local Economic Development. International Journal of Public Sector Management, 25(2), 133 - 153.

Odhiambo, W. \& Kamau, P. (2003). Public Procurement: Lessons from Kenya, Tanzania and Uganda. OECD Development Centre Working Paper No. 208.

OECD. (2015). OECD Recommendation of the Council on Public Procurement. Available from: https://www.oecd.org/gov/public-procurement/recommendation/.

Pauw, J.C. 2011. Public Procurement and Supply Chain Management. Study Guide, Programme in Public Procurement and Supply Management. Pretoria, South Africa: Centre for Business Management, University of South Africa.

Sheoraj, R. (2007). The State of Skills Readiness in the South Africa Public Service: An Overview of Provincial and Local Government. Master's Dissertation, University of Pretoria, South Africa.

Theodorakopoulos, N., Ram, M., \& Kakabadse, N. (2015). Procedural Justice in Procurement and Inclusive Interorganisational Relations: An Institutional Perspective. British Journal of Management, 26(2): $237-254$.

Management and Inclusive Interorganizational Relations: An Institutional Perspective. British Journal of Management, 26, 37-254.

Uyarra, E. \& Flanagan, K. (2009). Understanding the innovation impacts of public procurement. Manchester Business School Working Paper, No. 574.

van Zyl, L. E. (2014). Research Methodology for the Economic and Management Sciences. Essex: Pearson.

Watermeyer, R.B. (2011). Regulating Public Procurement in Southern Africa through International and National Standards. Public Procurement Regulation in Africa Conference, Stellenbosch.

Witjes, S., \& Lozano, R. (2016). Towards a More Circular Economy: Proposing a Framework Linking Sustainable Public Procurement and Sustainable Business Models. Resources, Conservation and Recycling, 112, 37-44.

World Bank. (2016). Poverty and Shared Prosperity 2016: Taking on Inequality. World Bank, Washington, DC. Available from https://www.worldbank.org/en/publication/poverty-and-shared-prosperity-2016. 